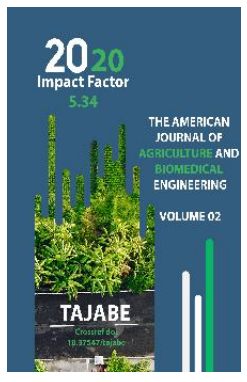

Journal Website: http://usajournalshub.c om/index,php/tajabe

Copyright: Original content from this work may be used under the terms of the creative commons attributes 4.0 licence.

\section{Bioecology Of Orchard Mites And The Effectiveness Of Modern Insecticides Against Them}

\author{
Shukurov Khushvaqt \\ Plant Protection Research Institute, Tashkent, Uzbekistan \\ Abduraxmanova Jamila \\ Plant Protection Research Institute, Tashkent, Uzbekistan \\ Nazarov Shaxzod \\ Plant Protection Research Institute, Tashkent, Uzbekistan \\ Mavlonova Nasiba \\ Plant Protection Research Institute, Tashkent, Uzbekistan \\ Muminova Rano \\ Plant Protection Research Institute, Tashkent, Uzbekistan \\ Nazarova Moxichexra \\ Plant Protection Research Institute, Tashkent, Uzbekistan
}

\title{
ABSTRACT
}

The article identifies the development of bugs, their biological properties, and the presence of more than 10 species of natural enemies, which reduce their number in the agrobiocenosis of seed orchards. $24 \%$ of Spiromectin vaccines (0,25 ha/l), 50\% n.p. (0,33 ha/l), Universal $25 \%$ s.g. (0,2 ha/l) insectoacaracids were tested against bugs, and as a androgen variant, Himgold had $72 \% \mathrm{em} .(1,0 \mathrm{ha} / \mathrm{l}$.) drug was selected. Chemicals have been found to reduce the number of phytophagous bugs and their natural enemies. According to the results of the experiments, all insectoacaricides, except for the Universal $25 \%$ s.d.g., were highly effective against spidermites.

\section{KEYWORDS}

Bioecology, effectiveness, acaricide, biological, chemical, ignited, insecticide, drug, diapause, winter, agrobiocenosis, thymus, entomophagus. 


\section{INTRODUCTION}

One of the main pests in the agro-biocenosis of seed orchards of our republic is a number of spider species. According to many authors, spiders have long been reported to be the most common pests in chemically treated orchards [8; 9; 10;].

Our observations revealed that during the 2016-2019 period in the orchards growing under the conditions of our Republic, 6 species of bugs were encountered. These are the pear swell-forming mite (Eriophyespyri), the brown fruit mite (Briobiaredikorzev), the garden spider mite (Schizotetranychuspruni), the red hawthorn mite (Amphitetranichusviennensis), the common flat-bodied spider mite (Tetranychusurticaali).

Among these pests, 3 species common spider mite (Tetranychusurticae), garden spider mite (Schizotetranychuspruni), red hawthorn mite (Amphitetranichusviennensis) were recorded as the most common major pest. Garden spider mites and hawthorn mites multiply in the second half of summer and pose a serious threat to the yield of orchards. Although brown fruit cane is considered dangerous, it is observed to increase in spring and the first half of summer. In spring and the first half of summer, complex-acting insecticides (drugs approved for use in production) keep these pests at an economically safe level. In our experimental fields, the average amount of garden brown mite per 1 leaf did not exceed 0,7 replicatesduring 2016-2019.

\section{MITE BIOECOLOGY}

Garden spider mite -Schizotetranychus prune Oudms - slightly smaller $(400 \times 200 \mu \mathrm{m})$, elongated species, green-yellow in summer and orange-red in winter, with 13 pairs of feathers on the shoulders in transverse rows.
The eggs are round $(110 \mu \mathrm{m})$, clear, fuzzyyellow $[1 ; 4 ; 6 ;]$.

According to the author, who studied the biology and ecology of this pest in seed orchards, this type of mites reproduces by giving 10-12 generations per year. Females overwinter in cracks in the bark of trees. In the spring, as the leaves of the tree begin to shed, they wake up and get extra nutrition. During the remaining lifespan (40-60 days) it lays 50 eggs in total and starts a new joint. Wintering begins in August and lasts 2,0-2,5 months [13; 15;].

During the winter break, the mites are dark brown. When the average air temperature is + $8,5-9,0$ OC and the buds begin to swell in early spring, these mites begin to break out of the winter range and this condition is observed until October. During the years of the study, the end of wintering of these mites in the conditions of Kibray district of Tashkent region coincided with the second half of March. But in some years in gardens close to mountainous areas this period was observed in early April. For example, in 2017, end of wintering diapause of mites was observed on March 28, in 2018 on March 22, and in 2019 on March 26. However, in the mountainous areas of Bostanlyk district, the emergence of garden mites from the winter range was observed on April 2, 2017 and April 5, 2018. The mites, initially located on the sunny side of the trees, move towards the newly sprouting buds, and they feed by sucking the aphis.

They feed and reproduce by settling on the underside of the leaf until November. During this time, the garden spider mite produced 910 generations in the territory of Bostanlyk district, and in the territory of Kibray district 10-12 generations. From October until the 
onset of frost, their females entered the winter dormancy period.

\section{The redhawthorn mite,}

Amphytetranychusviennensis Zacher, has been described by many researchers as one of the main pests of orchards. [3; 6; 12;].

In the conditions of our country, hawthorn is still one of the most dangerous pests of orchards.
species.Mature breeds of these mites are also called red hawthorn mites because of their red color.The development cycle of the red hawthorn mite is like a garden spider mite, only going to winter a little later, in late October.Another difference of red hawthorn mite is that in the colonies formed during the winter dormancy, their number does not exceed 150 (Fig. 1).

The red hawthorn beetle also overwinters with the garden spider as a mature

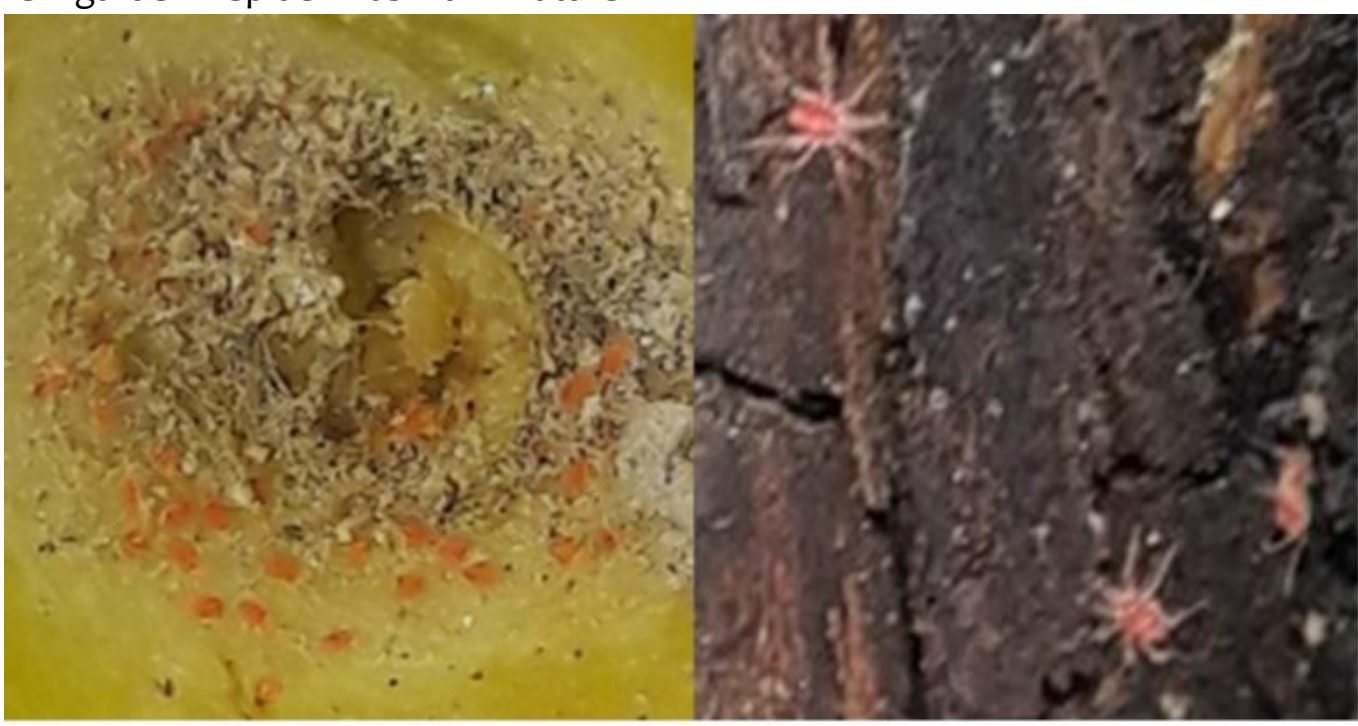

Fig.1.

Our observations show that the hawthorn mite also emerges from the winter diapause at the same time as the garden spider mite, and the female species begins to feed on the buds and leaves.These herbaceous mites begin to multiply by mid-summer. When seed fruit trees are damaged by more than $50 \%$ by mites, the appearance of next year's crop buds decreases sharply. Annual branches of strongly damaged trees do not exceed 10-12 $\mathrm{cm}$.If more than $80 \%$ of the trees are damaged, their branches will grow in the fall. As a result, the general condition of the trees deteriorates, they won't be ready for the winter dormancy period, and in most cases, they wither.

In our years of research, it has been found that infestation of apple orchards with spider mites affects their productivity and growth (Table 1).

The average yield in seed orchards observed in 2016-2019 was 48,8-105,2 cen I/ha. In the 9,2hectare apple orchard (Golden Delishes) of the "MadaniyatAzimovaSayyora" farm in Kibray district, $12,2 \%$ of trees were infested with spider mites in 2011, yielding an average of 105,2 quintals per hectare.In 2012, $18,6 \%$ of 
apple orchards in the observed areas were infested with spider mites, resulting in a yield of 75,6 cen I/ha, which is 29,6 cen I/ha less than in the previous year.In 2013, infestation of apple orchards with spider mites was 9,4\% and yields were 118 quintals per hectare.At the same time, it was observed that 12,8 quintals more than the harvest in 2016 and the growth of the branch was 2,6 cm longer.In 2019, the damage to fruit trees again increased and amounted to $14,6 \%$.And the yield was 87,2 cen I ha.Thus, the influence of spider mites in apple orchards is high, and it has been proven that they can greatly impair productivity when not controlled.

Table 1

Decreased productivity in apple orchards infested with spider mites.

(Tashkent region, Qibray district, "Culture AzimovaSayyora" farm)

\begin{tabular}{|c|c|c|c|c|c|}
\hline \multirow{2}{*}{$\begin{array}{c}\text { Years of } \\
\text { observation }\end{array}$} & \multirow{2}{*}{$\begin{array}{c}\text { Damage } \\
\text { rate, \% }\end{array}$} & $\begin{array}{r}\text { Average yield from 1 ha, } \\
\text { cen / ha }\end{array}$ & \multicolumn{2}{|c|}{$\begin{array}{r}\text { Average 1-year rod } \\
\text { length, cm }\end{array}$} \\
\cline { 3 - 6 } & & $\begin{array}{c}\text { In the year } \\
\text { of } \\
\text { observation }\end{array}$ & $\begin{array}{c}\text { Decrease } \\
\text { compared } \\
\text { to 2016 y. }\end{array}$ & $\begin{array}{c}\text { In the year } \\
\text { of } \\
\text { observation }\end{array}$ & $\begin{array}{c}\text { Decrease } \\
\text { compared } \\
\text { to 2016 y. }\end{array}$ \\
\hline $\mathbf{2 0 1 6}$ & 12,2 & 105,2 & - & 28,8 & - \\
\hline $\mathbf{2 0 1 7}$ & 18,6 & 75,6 & $-29,6$ & 20,6 & $-8,2$ \\
\hline $\mathbf{2 0 1 8}$ & 9,4 & 118 & $+12,8$ & 31,4 & $+2,6$ \\
\hline $\mathbf{2 0 1 9}$ & 14,6 & 87,2 & -18 & 26,6 & $-2,2$ \\
\hline
\end{tabular}

In the agrobiocenosis of seed orchards, there are more than 10 species of natural enemies that reduce the number of garden spider mites.

Of particular importance are the following: stetorus beetle (StetoruspunctillumWs.), Anthocoris caterpillar (Anthocoris sp.), Mite eating thrips (HaplotripsalpesterRiss.), Commongreenlacewing
(ChrysopacarneaSteph.), Wild mitephytoseigerids (phytoseyids). [5; 14; 15;].

Studies have shown that chemicals (insecticides) have a negative effect on natural entomophages in garden agrobiocenosis.The following table presents the results of experiments(Table 2 ).

As can be seen from the table, the ratio of acariphages and herbaceous mites in the 
The American Journal of Agriculture and Boimedical Engineering (ISSN - 2689-1018)

Published: September 26, 2020 | Pages: 48-57

Doi: https://doi.org/10.37547/tajabe/Volume02Issue09-09

2020: $5 \cdot 34$

control variant was 1:310,0; 1:141,3, and 1:97,0 in the tree leaves in the control variant.lall variants, the density of enemies was not enough to reduce the number of spider mites to an economically harmless level.Therefore, there was definitely a need to use an effective acaricide.

Table 2

Changes in the ratio of garden spiders and acariphages in areas chemically treated with GOLD BI 58 $40 \%$ em.k (2.0 l/ha)

(Qibray district «MadaniyatAzimovaSayyora» $\mathrm{f} / \mathrm{x}$, prep. Sowing time 09.06.2019)

\begin{tabular}{|c|c|c|c|c|}
\hline \multirow{3}{*}{ Options } & \multirow{2}{*}{$\begin{array}{l}\text { Reporte } \\
\text { d days }\end{array}$} & \multicolumn{2}{|c|}{$\begin{array}{c}\text { Average number of leaves per } \\
\text { 1, pcs }\end{array}$} & $\begin{array}{c}\text { Number of mite } \\
\text { relative to 1 } \\
\text { enemy, pcs }\end{array}$ \\
\cline { 2 - 5 } & Mites & acariphages & $1: 310,0$ \\
\hline \multirow{4}{*}{ Control } & 30.05 & $31 \pm 2,9$ & $0,1 \pm 0,01$ & $1: 141,3$ \\
\cline { 2 - 5 } & 10.06 & $325 \pm 17,2$ & $2,3 \pm 0,73$ & $1: 97,0$ \\
\cline { 2 - 5 } & 20.06 & $291 \pm 23,2$ & $3,0 \pm 0,44$ & \\
\hline \multirow{3}{*}{ Experience } & 09.06 & $211,2 \pm 13,1$ & $1,9 \pm 0,7$ & $1: 111,0$ \\
\cline { 2 - 5 } & 10.06 & $13,1 \pm 0,9$ & & $1: 0,0$ \\
\cline { 2 - 5 } & 20.06 & $7,7 \pm 1,03$ & $0,2 \pm 0,11$ & $1: 38,5$ \\
\cline { 2 - 5 } & 30.06 & $21,3 \pm 2,7$ & $1,4 \pm 0,03$ & $1: 15,2$ \\
\cline { 2 - 5 } & & until processing & \\
\hline
\end{tabular}

Summarizing from the table, the chemicals not only reduce the number of phytophagous mites, but also destroy their natural cousins.In this case, the recovery of spider mite populations after processing iss faster than that of enemies.Acariphages usually cannot bring the number of mites to a level that is harmless to the farm.

\section{RESEARCH METHOD}

Research was carried out according to the special methodical instructions published in the edition of Sh.T. Khodjaev (2004) [2].The presence of mite eggs on the tree branches was checked using a hand magnifier.To do this, after flowering, the lower part of 10 tree branches were taken from 4 parts by 10 
leaves, a total of 40 (4 in reverse) and they were fully examined, and it was found that they had adult mites and their larvae.

\section{RESULTS}

One of the main pests of orchards is spider mites.In conditions of Uzbekistan, the common spider mite reproduces by giving 1215 generations. The reproduction of spider mites is directly related to their nutrient environment.Especially when their females are fed with protein-rich plants, they are prolific and the time required for the development of a generation is also reduced.

During 2016-2019, we conducted research to study the developmental characteristics of spider mites in seed orchard areas and the biological effectiveness of chemicals against them.

In 2016-2019 we conducted a small field experiment to study the effectiveness of chemicals against spider mites in the orchards of "MadaniyatAzimovaSayyora" farm in Kibray district of Tashkent region. In the gardens, 4 types of anti-spider mite chemicals (acaricides and insecticides) Pyridaben 50\% 0,30-0,33 l/ha, Universal $25 \%$ s.d.g. 0,15- 0,2 l/ha, Spiromectin $24 \%$ em.k. 0,20-0,25 I/ha, Ximgoldem.k. 0,8 -1,0 I/ha, the consumption rate was tested.In the control variant, the spider mites were not treated with acaricides.The drugs were applied using a sprayer OPV-1200 with a flow rate of $1000 \mathrm{l} / \mathrm{ha}$.According to the results of our research, in the orchard against spider mites Pyridaben 50\% n.kuk was applied at a rate of $0,30 \mathrm{l} / \mathrm{ha}$, the efficiency was $84,1 \%$ compared to the control on 7 reported days, and when was applied at the rate of $0,33 \mathrm{l} / \mathrm{ha}$ showed effectiveness by $83,6 \%$. By the 14 th day of the reporting period, these indices were 93,8-95,2\%, respectively. (See Table 3).

In our variant, where the universal drug $25 \%$ s.d.g was consumed at a rate of $0,15 \mathrm{l} / \mathrm{ha}$, the biological efficiency was $80,2 \%$ on day 7 , while on day 14 this figure reached $85,5 \%$. When this drug was used at a rate of $0,2 \mathrm{l} / \mathrm{ha}$, the biological efficiency reached 90,1-96,1\% compared to control.Spiromectin $24 \% \mathrm{em}$. preparation at a dose of $2,01 /$ ha has the highest efficacy with $81,7 \%$ on day $7,90,6 \%$ on day 14 , and $89,9 \%$ on day 7 at a dose of 0,3 I/ha. and $96,3 \%$ on the 14 th day.

In the variant in which the anti-spider mite drug Himgold $72 \%$ emk was applied at a rate of $0,8 \mathrm{I} / \mathrm{ha}$, achived biological efficiency on day 3 was $73,9 \%$ compared to control, on day 7 of our experiment it was $82,8 \%$ and on day 14 it was $90,7 \%$. In the variant in which the drug was consumed at a rate of $0,25 \mathrm{l} / \mathrm{ha}$, the efficiency was $71,7-90,2 \%$ and $96,4 \%$, respectively, compared to the control. 
Table 3

Biological effectiveness of acaricides against spider mites in seed orchards.

("MadaniyatAzimovaSayyora" farm, Qibray district, Tashkent region. Small field experience, working fluid consumption $1000 \mathrm{l} / \mathrm{ha}$, 2018-2019)

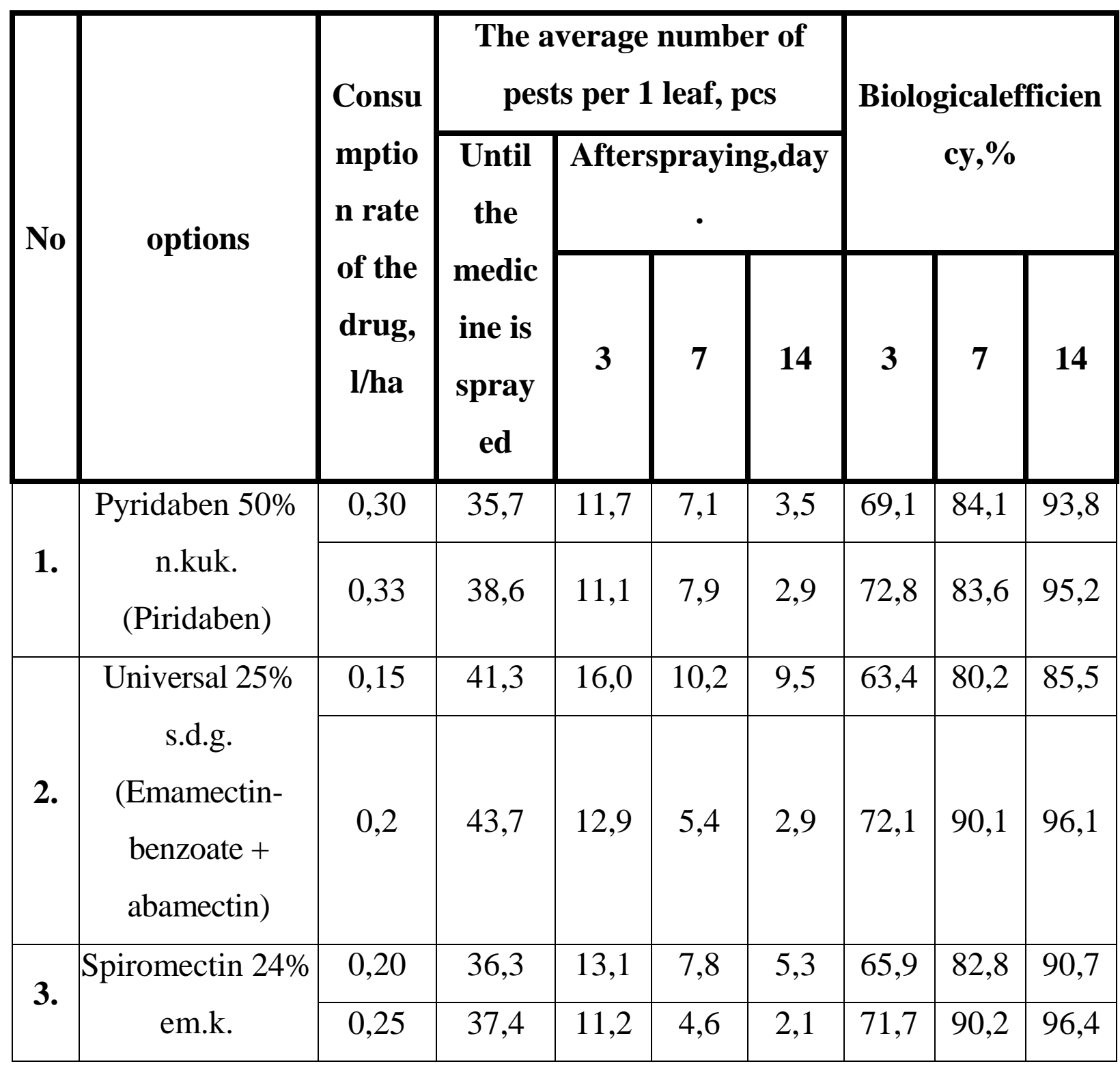




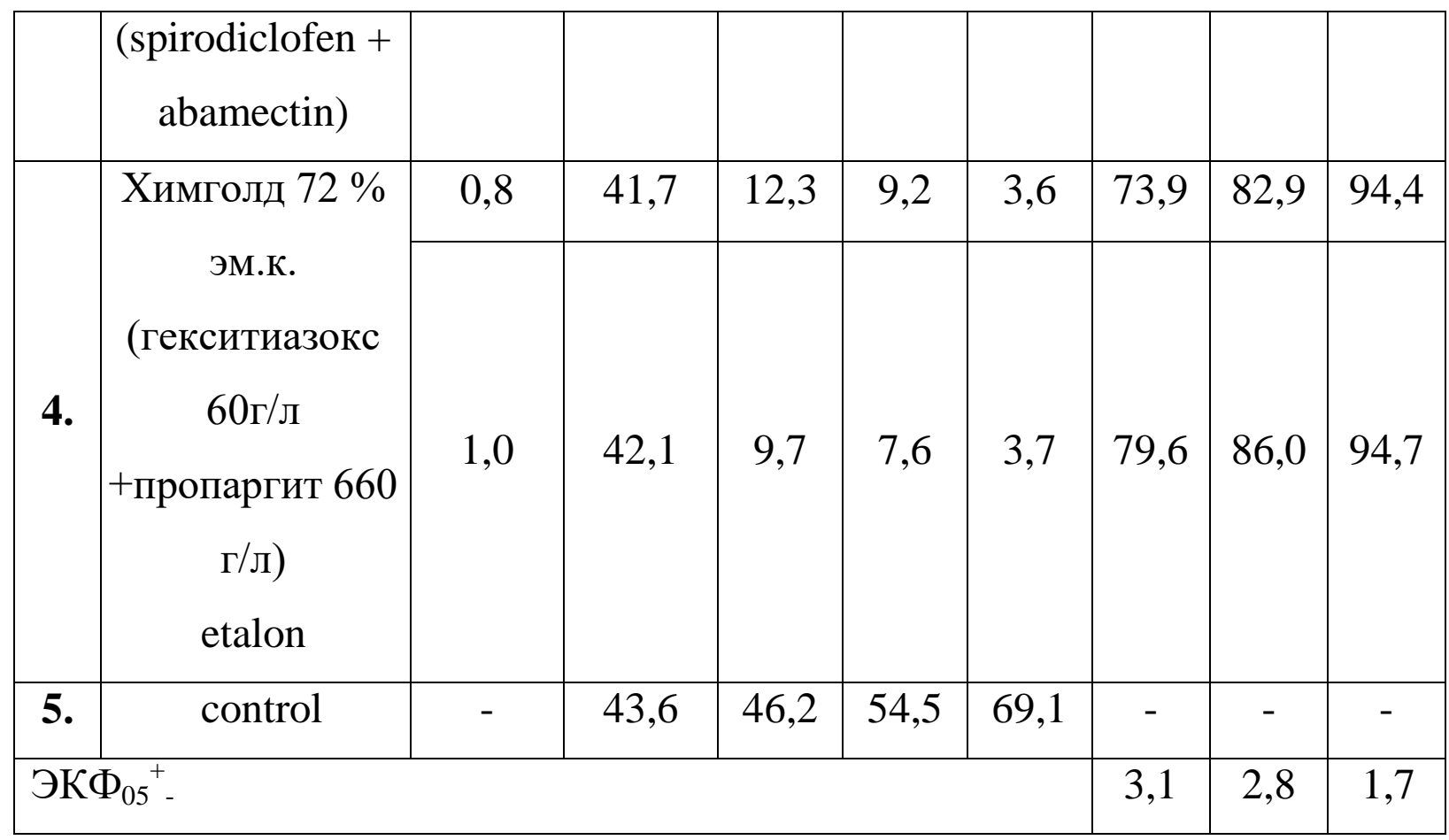

In small field experiments, the most effective doses of the drugs were selected and applied over a wide area against spiders under production conditions. The results obtained in the production experiments are given below. From these data, it can be seen that the drugs in all our experiments showed satisfactory results.

In experiments, four modern acaricides and insecticide-acaricides were tested: Spiromectin 24\% em.k.-0.25 ha/l, Pyridaben 50\% n.kuk. $-0.33 \mathrm{ha} / \mathrm{l}$ and Universal 25\% s.d.g. 0,2 ha/l, Ximgold -1,0 ha/l. (Figure 2).

According to the results of our study, Spiromectin $24 \%$ em.k at a rate of $0.25 \mathrm{l} / \mathrm{ha}$, after treatment on the 3rd day of treatment achieved $92.9 \%$ biological efficiency compared to control and by the 7th day of treatment, the biological efficiency reached 100\% compared to control. The highest biological efficacy was observed on day 14 and was $95.3 \%$.

Also, in the variant in which the drug Pyridaben $50 \%$ n.kuk was used at a rate of 0.33 I/ha, on the 3 rd day of calculation, the biological efficiency was $87,0 \%$ compared to control, on the 7 th day of calculation it was $93,8 \%$ and on the 14 th day it was $91,3 \%$.

In the variant in which the next Universal 25\% s.d.g was applied at a rate of $0.2 \mathrm{l} / \mathrm{ha}$, the biological efficacy was $22,8 \%$ compared to control on day $3,77,3 \%$ on day 7 , and on day 14 the figure rose to $61,9 \%$.In our next standard variant, Ximgold72\% em.k when used at 1.0 I/ha, while the biological efficiency was $86,4 \%$ on day $3,94,0 \%$ on day 7 compared to control and by the 14 th day, it was $93,3 \%$. 


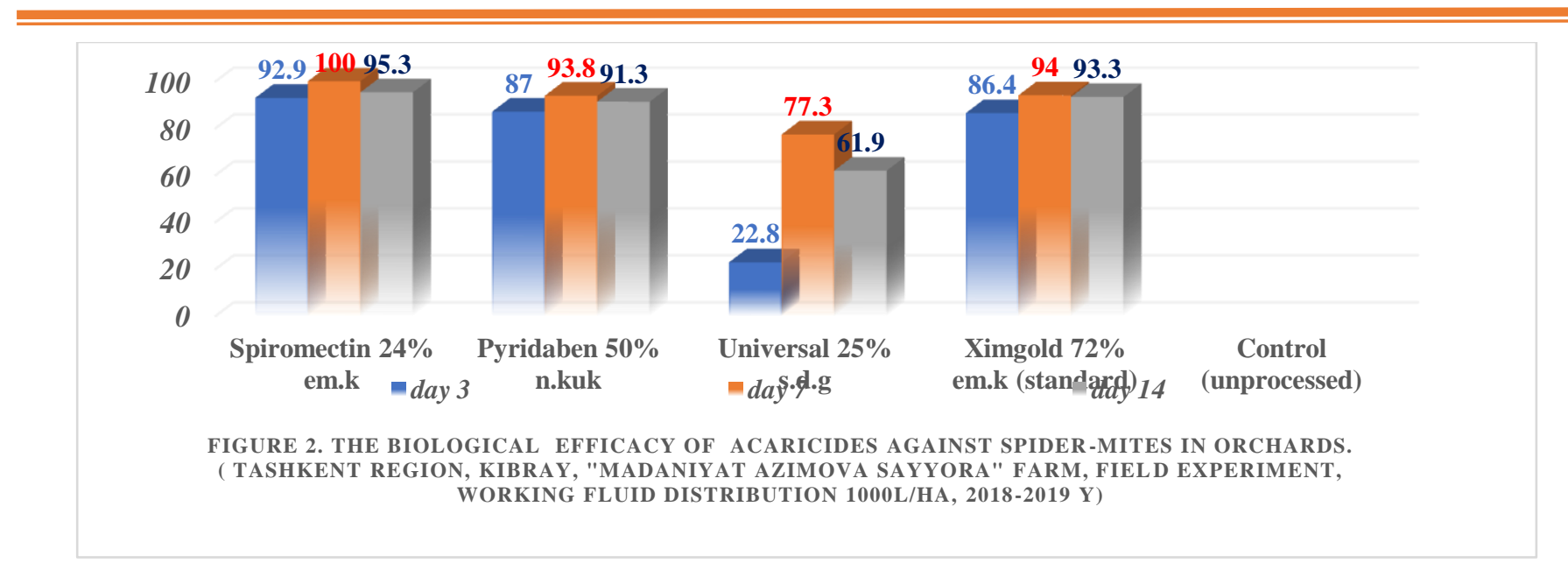

The results of the experiments show that all insecticides except Universal 25\% s.d.g showed high biological efficacy against spidermites.Although there was no short-term use of these drugs, no signs of resistance were observed in the populations tested against them.

\section{CONCLUSION}

Our observations revealed the occurrence of 6 species of herbivorous canals in the orchards grown in the conditions of the Republic in 2016-2019. These are: the pear-shaped mite (Eriophyespyri), the brown fruit mite (Briobiaredikorzev), the garden spidermite (Schizotetranychuspruni), the red hawthorn mite (Amphitetranichusviennensis), the common spidermite (Tetranychusurticaali) a species of flat-bodied mite (Cenopalpuspulcher) have been detected.

Among these pests, 3 species - common spidermites (Tetranychusurticae), garden spidermite (Schizotetranychuspruni), red hawthorn mite (Amphitetranichusviennensis), were recorded as the most commonly dangerous major dominant species.

It was observed that they feed on the lower part of the leaf and continue to reproduce until November, during which time the garden spider reproduces by giving 9-10 generations in Bostanlyk district of Tashkent region and 1012 generations in Kibray district.

In our years of research, it has been found that infestation of apple orchards with spidermites affects the yield obtained and the growth of twigs.

In the agrobiocenosis of seed orchards, it was noted that there are more than 10 species of natural enemies that reduce the number of garden spidermites.

Of particular importance are the following: stetorus beetle (StetoruspunctillumWs.), Anthocoris caterpillar (Anthocoris sp.), thrips (HaplotripsalpesterRiss.), Common green lacewing(ChrysopacarneaSteph.), Wild mitephytoseyid (Phytoseyid).

Spiromectin 24\% em.k. (0.25 ha/l), Piridaben $50 \%$ n.kuk. (0,33ha/l), Universal $25 \%$ s.d.g. (0,2 $\mathrm{ha} / \mathrm{l})$ insecticides were tested and Ximgold $72 \%$ em.k (1,0 ha/l.) was selected as the standard variant.

Compared to the control variant of tested acaricides and insecticides Spiromectin 24\% em.k. demonstrated efficiency at $100 \%$ on day 7, Pyridaben $50 \%$ n.kuk drug $93,8 \%$ on the same 
day, Universal $25 \%$ s.d.g drug 77,3\%.The template variant Ximgold $72 \%$ em.k drug on day 7 achieved $94 \%$ efficacy.

Chemicals have been found to reduce the number of phytophagous mites as well as their natural enemies. According to the results obtained in the experiments, all insect acaricides except Universal 25\% s.d.g have achieved high biological efficacy against spidermites.

\section{REFERENCES}

1. Akhtar MS, Rafi U, Usmani MK, Dey D A review of aphid parasitoids (Hymenoptera: Braconidae) of Uttar Pradesh and Uttarakhand, India. Biology and Medicine, 2011. 3 (2) Special Issue: -P. 320-323.

2. Alekseeva S.A., Bystraya G.V., Yagubyan S.K., Nagoev B.N. Search for effective insecticides against pear psylla. Plant protection an quarantine, 2010, No. 10, pp. 28-31 (in Russian).

3. Amrine, J.W. Stasny, T.A. and Flechtman, H.W.C., Revised Keys to World Genera of Eriophyidea (Acari: Prostigmata). Indira Publishing House, West Bloomfield, MI. 2003. 798 pp.

4. Bayeva V.G., Nurmamatov A.M. Pear psylla. Plant Protection and Quarantine (Moscow), 1990, No. 7, pp. 30-31 (in Russian).

5. Denizhan, E. Monfreda, R. Çobanoglu, S. and de Lillo, E. Three new Aceria species (Acari: Eriophyoidea) from Turkey. International Journal of Acarology, 2006. 32 (2), 179-184. SỆ:

6. Denizhan, E. Monfreda, R. De Lillo, E. and Çobanoglu, S., Eriophyoid mite fauna (Acari: Trombidiformes: Eriophyoidea) of Turkey: new species, new distribution and an updates catalogue). Zootaxa, 3991 2015. (1): 001-063.

7. JusupovA.Kh. Moth-Apple Pests. //International Journal of Applied Agricultural Research. ISSN 0973-2683. - Volume 10,Number 1 (2015). -P. 4346.

8. KhodjaevSh.T. Instructions on testing insecticides, acaricides, biologically active substances and fungicides. 2nd ed. Tashkent, 2004, 103 pp. (in Uzbek).

9. KhodjaevSh.T. Modern methods and means of the integrated pest protection of plants. Tashkent: "Navrooz", 2015, 552 pp. (in Uzbek).

10. Polyakova T.E. Insect enemies of Psyllidae and their role in regulation of pest numbers in Belorussia. Pages 1920 in: The urging problems of the biological plant protection. Minsk, 1998 (in Russian).

11. ShukurovKh., Mamarahimov N., Akhmedov A. The worst pear pests. Agriculture of Uzbekistan, 2012, No. 2, pp. 33-34 (in Uzbek).

12. Takafuji A., Chant D.A. Comparative studies of two species of predacions phytoseiid mites(Acariña: Phytoseiidae) with special reference to their responses to the density of their prey. Res.Popul.Ecol. Kyoto Univ., 1976, 17. 255-310.

13. Tanja Gotlin Čuljak, Jasminka Igrc Barčić, Renata Bažok, Dinka Grubišić. APHID FAUNA (HEMIPTERA: APHIDOIDEA) IN CROATIA. // Department for Agricultural Zoology, Faculty of Agriculture, University of Zagreb, Entomol. Croat. 2005, Vol. 9. № 1-2: -P. 57-69.

14. http://dx.doi.org/10.1080/01647950608 684458 